$\operatorname{Nr} 8$

WARSZAWA-KRAKÓW 2006

\author{
ANDRZEJ WIELOŃSKI, KATARZYNA SZMIGIEL \\ Uniwersytet Warszawski
}

\title{
Europejskie uwarunkowania rozwoju sektora małych i średnich przedsiębiorstw w Polsce
}

Cechą charakterystyczną gospodarki Unii Europejskiej jest znaczący w niej udział sektora małych i średnich przedsiębiorstw - MSP*. Przedsiębiorstwa te, w porównaniu z przedsiębiorstwami dużymi, w tym zwłaszcza spółkami akcyjnymi, są słabszymi podmiotami gospodarczymi. Ich znacznie mniejsze możliwości pozyskiwania kapitału i zaawansowanych technologii powodują, że są w dużym stopniu zagrożone upadłością. Jednak dzięki aktywnej polityce wspierania prywatnej przedsiębiorczości liczba nowo powstających przewyższa liczbę tych, którym się nie powiodło (Leśniewski 2003). Polityka ta opiera się na założeniu, że sektor MSP przyczynia się do powstawania klasy średniej, której istnienie jest warunkiem stabilnej demokracji oraz przeciwdziała procesom koncentracji w gospodarce rynkowej i jej monopolizacji, ograniczającym wolny wybór i konkurencję (Ważniewski 2003). Istotną jej częścią są programy wspólnotowe i fundusze strukturalne. W tym jednak przypadku o pomoc mogą ubiegać się przedsiębiorstwa, które w poprzednim roku obrotowym zatrudniały średnio mniej niż 249 pracowników, osiagały przychód ze sprzedaży towarów, wyrobów i usług oraz operacji finansowych nie przekraczający $40 \mathrm{mln}$ euro lub suma aktywów ich bilansów sporządzanych na koniec poprzedniego roku obrotowego nie przekroczyła $27 \mathrm{mln}$ euro (Leśniewski 2003). Ponadto nie zalicza się do małych i średnich przedsiębiorstw takich, w których przedsiębiorcy inni niż mali i średni posiadają więcej niż $25 \%$ wkładów, udziałów lub akcji, jak też prawa do udziału w zysku lub głosów w zgromadzeniu wspólników lub akcjonariuszy.

Funkcjonujący w Polsce po II wojnie światowej model gospodarki nakazowej, preferujący sektor dużych przedsiębiorstw państwowych, wyeliminował takie pojęcia jak rynek, konkurencja, wolny wybór, klasa średnia i przedsiębiorczość. Znaczącą rolę odegrał w tym system podatkowy, charakteryzujący się w stosunku do sektora prywatnego przewagą funkcji fiskalnej nad funkcją stymulacyjną. W rezultacie celem działalności większości małych i średnich przedsiębiorstw prywatnych była głównie maksymalizacja dochodów rodziny. Dopiero zapoczątkowana w 1990 r. transformacja systemu gospodarczego, obejmująca

\footnotetext{
* Najczęściej stosowanym kryterium przy określaniu wielkości przedsiębiorstwa jest liczba zatrudnionych. W porównaniach międzynarodowych przedsiębiorstwa zatrudniające do 49 osób są zaliczane do małych, natomiast zatrudniające od 50 do 249 osób do średnich.

** Dla prowadzenia działalności gospodarczej istotne są: niskie podatki, elastyczny rynek pracy, dobra infrastruktura, wysoka jakość instytucji, stabilność warunków działania i tani pieniądz. W przypadku przedsiębiorstw dużych czynniki te decydują o lokalizacji inwestycji, natomiast w przypadku przedsiębiorstw małych i średnich o ich przetrwaniu.
} 
przekształcenia instytucjonalno-ekonomiczne i restrukturyzację gospodarki, usunęła wiele barier administracyjno-prawnych ograniczających prywatną przedsiębiorczość. Efektem tego był rozwój sektora małych i średnich przedsiębiorstw. Szczególnie wysoki wzrost liczby przedsiębiorstw nastąpił w latach 1990-1993, na które przypadła faza eksplozji prywatnej przedsiębiorczości. Po wyczerpaniu się prostych rezerw, przekształciła się ona w fazę samoregulacji rynkowej, w której o liczbie przedsiębiorstw decyduje konkurencja.

W 2002 r. sektor MSP liczył ponad 1,6 mln aktywnych przedsiębiorstw działających w większości na lokalnych rynkach, wśród których przedsiębiorstwa przemysłowe stanowiły około 12\% (Rachtan 2003). Integracja Polski z Unią Europejską spowoduje, że od 1 maja 2004 r. staną się one częścią jednolitego rynku europejskiego. Wykorzystanie szansy, jaką stanowią unijne środki pomocowe przeznaczone na wzrost konkurencyjności (np. na poszerzanie oferty produktowej), i dostosowanie MSP do wymagań Unii Europejskiej (np. w zakresie ochrony środowiska) może okazać się dla wielu małych i średnich przedsiębiorstw warunkiem przetrwania na rynku. Dotychczas upatrują one swojej przewagi konkurencyjnej w stosunku do przedsiębiorstw zagranicznych nie w innowacyjności, sposobie dostarczania produktów do klienta czy jakości, ale w niskich kosztach i możliwości obniżenia cen.

Unijne środki pomocowe stanowią część pomocy zagranicznej udzielanej polskim MSP właściwie od początku transformacji. Zasadniczo istnieją jej dwa rodzaje. Pierwszy wywodzi się z szeroko pojętej współpracy bilateralnej, drugi to programy oferowane przez Unię Europejską. Pomoc zagraniczna udzielana jest w różnej formie. Może to być pomoc finansowa w postaci dotacji, pożyczki lub kredytu, pomoc techniczna w postaci doradztwa prawno-organizacyjnego, przekazywania informacji na temat dostępnych środków finansowych czy wymiany doświadczeń. Programy bilateralne to programy służące nawiązywaniu kontaktów handlowych przez firmy z państwa udzielającego dotacji lub pomocy technicznej z firmami w państwie, w którym pomoc jest udzielana. Najczęściej są koordynowane przez ambasady i konsulaty. W tej kategorii szczegółowo sprecyzowanych programów więcej jest z krajów spoza Europy. Przy czym wiele ambasad europejskich deklaruje tego typu pomoc, bez oferowania konkretnych programów. Specyficzną grupę stanowią programy oferowane przez ONZ, ich ogólnym celem jest pomoc w rozwijaniu nowoczesnej gospodarki rynkowej poprzez pomoc MSP.

Najważniejszym funduszem pomocowym oferowanym Polsce od początku procesów integracyjnych Polski z Unią Europejską jest fundusz PHARE. Pierwsze cele tego funduszu związane były z usprawnianiem transformacji - budowaniem społeczeństwa obywatelskiego i gospodarki rynkowej, aby przygotować polską gospodarkę do integracji europejskiej. W 1997 roku cele zostały zmodyfikowane. Nadal nadrzędnym zadaniem pozostało przygotowanie polskich przedsiębiorstw do integracji, ale tym razem poprzez przygotowanie ich do konkurowania na jednolitym rynku europejskim (Tworos 2000). Szczegółowe cele programów Unii Europejskiej oferowanych MSP ewoluują wraz ze zmianami w ogólnej polityce Unii Europejskiej. Obecne cele wpisują się w strategię rozwoju społeczno-gospodarczego sformułowaną w Strategii Lizbońskiej, zakładającej, że do 2010 roku Unia stanie się „,najbardziej konkurencyjną i dynamiczną, opartą na wiedzy gospodarką na świecie, zdolną do trwałego rozwoju, tworzącą większą liczbę lepszych miejsc pracy oraz charakteryzującą się większa spójnością społeczną" (Grzelakowski, Jasiński et 2003).

Przedsiębiorstwa, które korzystają z pomocy Unii Europejskiej, muszą spełniać określone, ogólne dla wszystkich programów przedakcesyjnych warunki:

- nie mogą mieć nieuregulowanych zobowiązań wobec państwa, 
- muszą dofinansować przedsięwzięcie (od 40\% do 75\%),

- ponoszą bezpośrednią odpowiedzialność za przygotowanie realizowanych projektów i za nadzór nad ich realizacją.

Instytucją nadzorująca politykę sektorową wobec małych i średnich przedsiębiorstw jest Polska Agencja Rozwoju Przedsiębiorczości (PARP). Koordynuje ona wszystkie programy unijne dla MSP. Ważnym działaniem PARP było stworzenie sieci regionalnych instytucji finansujących (RIF). Nadzorują one nie tylko programy wdrażane regionalne, ale również programy oferowane na tych samych zasadach w całym kraju. Kontaktując się bezpośrednio z firmami, urzędami marszałkowskimi i wojewódzkimi urzędami pracy koordynują wszystkie programy na rzecz rozwoju przedsiębiorczości z funduszu PHARE. Powstały poprzez podpisanie umów z działającymi wcześniej na rynku regionalnym instytucjami. Najczęściej są to agencje rozwoju regionalnego. Natomiast na poziomie lokalnym działają punkty konsultacyjno-doradcze (PKD). Przedsiębiorcy mogą za ich pośrednictwem otrzymać bezpłatne porady o sposobach wypełniania i gromadzenia potrzebnej dokumentacji.

Fundusze ze środków pomocowych programowane są zgodnie z obowiązującym okresem budżetowym w Unii Europejskiej. W latach 2000-2006 dokumentem regulującym zasady wdrażania funduszu PHARE jest rozporządzenie Rady Unii Europejskiej z 21 czerwca 1999 dotyczące koordynacji pomocy w ramach strategii przedakcesyjnej dla krajów ubiegających się o członkostwo w Unii Europejskiej (Guz-Vetter 2001). Ponadto co roku negocjowane są Wytyczne Komisji Europejskiej dotyczące priorytetów programu na dany rok.

Zgodnie ze wspomnianym rozporządzeniem w latach 2000-2006 fundusz PHARE „będzie koncentrować się na zasadniczych priorytetach związanych z przejmowaniem ,acquis communautaire", to jest na wzmacnianiu zdolności administracyjnych i instytucjonalnych krajów kandydujących oraz na finansowaniu inwestycji mających na celu pomoc tym krajom w jak najszybszym osiąnięciu zgodności z prawem wspólnotowym" (zob. PHARE 2000...). Takie określenie celu funduszu zawęża możliwości aplikowania o środki wspólnotowe do celów związanych z dostosowaniem przedsiębiorstw do unijnych standardów.

Uruchomiono już programy PHARE 2000 i PHARE 2001. Podpisano również wszystkie memoranda finansowe do PHARE 2002 i pierwsze do PHARE 2003. Dotacje z PHARE 2000 dla przedsiębiorstw podzielone były na dwa rodzaje programów. Część z nich to programy ogólnokrajowe, dostępne dla przedsiębiorstw we wszystkich województwach w ramach Krajowego Programu Rozwoju MSP:

- „Wstęp do jakości” - program dofinansowania usług doradczych i szkoleniowych związanych z podnoszeniem jakości produktu; budżet programu: 1,33 mln euro;

- „Innowacje i technologie dla rozwoju przedsiębiorstw” - program współfinansowania kosztów usług szkoleniowych i doradczych dla przedsiębiorców, którzy rozwijają swoje firmy poprzez wdrażanie rozwiązań innowacyjnych i nowych technologii; budżet programu: 1,33 mln euro;

- „Przygotowanie do działania na rynku europejskim” - program obejmuje dotacje dla przedsiębiorstw prywatyzowanych drogą leasingu pracowniczego, znajdujących się na liście Ministerstwa Skarbu Państwa; budżet programu: 1,33 mln euro.

Drugą część stanowią programy w ramach PHARE 2000 Spójność Społeczno-Gospodarcza, czyli dostępne dla przedsiębiorstw położonych w województwach objętych tym programem - warmińsko-mazurskim, podlaskim, lubelskim, podkarpackim i śląskim. Budżet dla wszystkich programów wynosił około 21 mln euro (Guz-Vetter 2001): 
- Program rozwoju przedsiębiorstw - dotacje na usługi szkoleniowo-doradcze, poprawa konkurencyjności firmy poprzez opracowywanie wewnętrznych programów rozwoju;

- Program rozwoju przedsiębiorstw eksportowych - dotacje na rozwój działalności eksportowej;

- Fundusz dotacji inwestycyjnych - wsparcie projektów inwestycyjnych.

Dotacje z funduszu PHARE 2001 dla przedsiębiorstw w całości realizowane są z PHARE 2001 Spójność Społeczno-Gospodarcza, ale dostępne są na tych samych zasadach w całym kraju. Realizowane są one w ramach programu Promocja Małych i Średnich Przedsiębiorstw PHARE 2001. Podzielono go na cztery komponenty:

- Program rozwoju przedsiębiorstw;

- Program rozwoju firmy dla eksporterów;

- Fundusz dotacji inwestycyjnych;

- Program rozwoju firm internetowych - dotacje dla firm rozwijających się w oparciu o technologie internetowe.

Dotacje $\mathrm{z}$ funduszu PHARE 2002 uruchomione będą najwcześniej w pierwszym kwartale 2004 roku. Wiadomo, iż realizowane będą według dwóch ścieżek:

- Program dotacji dla przedsiębiorstw w Polsce - doradztwo i inwestycje związane z wdrażaniem nowych technologii, innowacji, rozwoju przedsiębiorstwa oraz wdrażania nowych certyfikatów;

- Program dotacji dla przedsiębiorstw w wybranych regionach - dotacje inwestycyjne oraz dotacje na zwrot kosztów konsultacyjnych i szkoleniowych (www.delpol.pl 2003).

Innym unijnym źródłem finansowania rozwoju przedsiębiorczości jest przedakcesyjny program SAPARD, którego podstawowym celem jest rozwój terenów wiejskich. Przewidziane w nim zostały środki na rozwój przedsiębiorczości na terenach wiejskich. Można w ramach funduszu finansować takie przedsięwzięcia, jak: budowa, modernizacja i adaptacja budynków, zakup maszyn i urządzeń, zagospodarowanie terenu, koszty marketingu, promocji, studiów wstępnych oraz dokumentacji technicznej.

Dla polskich przedsiębiorców dostępne są również niektóre programy wewnętrzne Unii Europejskiej. Najważniejsze z nich to: Euro Info Centr (EIC), Leonardo da Vinci, VI program Ramowy Badań i Rozwoju Technicznego Unii Europejskiej.

EIC jest elementem Wieloletniego Programu dla Przedsiębiorstw i Przedsiębiorczości UE. Jego działanie oparte jest na sieci instytucji regionalnych, udzielających informacji przedsiębiorcom na temat funkcjonowania UE (prawa i pomocy finansowej) oraz przekazujących swoje informacje na temat potrzeb MSP w danym kraju i regionie do Komisji Europejskiej.

Program Leonardo da Vinci koncentruje się na poprawie jakości szkolenia zawodowego. Projekty do programu mogą składać m.in. przedsiębiorstwa zaangażowane w dziedzinę kształcenia i szkolenia zawodowego. Jak większość wewnętrznych programów Unii Europejskiej i Inicjatyw Unijnych jest to program współpracy. Oznacza to, że podstawowym warunkiem uzyskania dotacji jest posiadanie w projekcie partnera z kraju członkowskiego.

VI Program ramowy Badań i Rozwoju Technicznego Unii Europejskiej wpisuje się w najnowsze postulaty UE o rozwoju społeczeństwa informacyjnego i gospodarki opartej na wiedzy. Jego celem jest zwiększenie współpracy pomiędzy sektorem badawczym a sektorem przedsiębiorstw. Zawiera komponenty skierowane specjalnie do MSP (Przewodnik dla wnioskodawców, Komisja Europejska 2002). 
Przedstawiony spis możliwych sposobów finansowania przedsiębiorstw małych i średnich wydaje się znaczący i ukierunkowany na wspomaganie nowoczesnego rozwoju sektora MSP w Polsce. Najważniejszą funkcją, jaką muszą spełnić przedstawione instrumenty finansowe, jest przystosowanie polskich MSP do konkurowania na rynku Unii Europejskiej, tzn. na rynkach bogatych państw, takich jak Niemcy czy Francja, ale także do konkurowania na rynku polskim z przedsiębiorstwami z bogatych państw z zachowaniem unijnych standardów. Obecnie polskie przedsiębiorstwa konkurują w dużo mniejszym zakresie, gdyż działają głównie na rynkach lokalnych (Rachtan 2003). Oznacza to, że wszystkie polskie przedsiębiorstwa muszą spełnić wymogi jakości UE, jakie już teraz spełniają MSP działające w krajach Unii, i aby przetrwać, muszą nauczyć się skutecznie konkurować.

Jedynym sposobem realizacji tych postulatów jest dostosowanie systemu dystrybucji funduszy do możliwości i sposobów działania polskich MSP oraz umożliwienie MSP nabycia doświadczenia w aplikowaniu o środki. Niemożliwe jest łagodzenie standardów prawnych oraz ekonomicznych obowiązujących w tym systemie. Niezbędne jest więc dostosowywanie systemu instytucjonalnego. Wydaje się, że system instytucjonalny powinien: docierać z najbardziej aktualną informacją do MSP (inicjować obieg informacji poprzez jej efektywną dystrybucję); być dobrze dostępny - udzielać porad i wskazówek na wszystkich etapach aplikowania o środki, a nawet przygotowywać przedsiębiorców do takiej aktywności; a także wspomagać uzyskanie niezbędnego finansowania dodatkowego.

Działania podejmowane przez PARP - organizowanie struktur regionalnych i lokalnych, wydają się iść w dobrym kierunku. Wydaje się również, że ważnym elementem tych działań powinno być aktywizowanie na rzecz procesu wdrażania funduszy europejskich instytucji działających w sektorze przedsiębiorstw. Przykładem takiej aktywności PARP jest powołanie w 1996 roku Krajowego Systemu Usług dla Małych i Średnich Przedsiębiorstw, zrzeszającego instytucje i przedsiębiorstwa świadczące usługi doradcze, szkoleniowe, informacyjne, finansowe i proinnowacyjne dla małych i średnich przedsiębiorstw. Jest to system wspierania MSP, który ma zapewnić dostępność i odpowiednią jakość usług niezbędnych do konkurencyjnego rozwoju MSP. Należą do niego instytucje niekomercyjne: ośrodki wspierania biznesu, agencje rozwoju itp., jak również instytucje komercyjne akredytowane jako usługodawcy dla MSP. W 1996 sieć liczyła 111 ośrodków, w kolejnych latach (odpowiednio 1997, 1998, 1999) powiększała się każdorazowo o kolejne 10 nowych akredytowanych ośrodków, obecnie jest ich około 180.

Dostępność dodatkowych środków dla przedsiębiorstw na terenach wiejskich wydaje się ważnym pozytywnym czynnikiem wspierającym. Są to przedsiębiorstwa funkcjonujące w specyficznych warunkach, wymagają więc specyficznych środków aktywizacji. Środki te dają możliwość specjalizacji systemu instytucjonalnego. Negatywna wydaję się całkowita odrębność struktur wdrażających te fundusze od struktur wdrażających pozostałe fundusze na rzecz rozwoju przedsiębiorczości.

W 2002 roku sektor MSP liczył 1,6 mln przedsiębiorstw, a za pośrednictwem PARP z pomocy skorzystało 8257 przedsiębiorstw, jest to około 0,5\% przedsiębiorców rocznie zdobywających doświadczenie w finansowaniu swojej działalności ze źródeł UE. W 2002 roku dotacje udzielone przez PARP wynosiły około 118 mln złotych, a można wstępnie zakładać, że w latach 2004-2006 dostępnych dla sektora przedsiębiorstw może być około 0,5 mld euro rocznie (oczywiście nie wszystkie te środki będą wdrażane przez PARP). Te bardzo ogólne wyliczenia pokazują, że zarówno skala, jak i tempo działań systemu instytucjonalnego przygotowanego na rzecz MSP ulegną zasadniczemu zwiększeniu pod wpływem funduszy strukturalnych. Jednak jeśli fundusze te w sektorze MSP mają zostać wykorzysta- 
ne, efektywność systemu musi być wysoka bez względu na skalę działań (wykorzystanie dla funduszy przedakcesyjnych wynosi ponad 90\%), a będzie to trudne ze względu na małe doświadczenie przedsiębiorców polskich w aplikowaniu o środki.

\section{Literatura}

Filipowicz O., 2003, Polskie MSP - unijne pieniadze, „Nowy Przemysł”, nr 9, s. 46-49

Gałczyńska M., 2002, Wsparcie matych i średnich przedsiębiorstw w ramach programu PHARE 2000 i 2001, [w:] Źródta finansowania dziatalności polskich przedsiębiorstw. Fundusze przedakcesyjne i strukturalne, Centrum Euro Info, Lublin

Grzelakowski A., Jasiński P., Streżyńska A., Szablewski A., Wodniak P., Żylicz T., 2003, Biała Księga, Część III. Liberalizacja i integracja rynków przemystów sieciowych. Trwaty rozwój, Warszawa

Guz-Vetter M., 2001, PHARE 2000 dla Polski Wschodniej i Ślaska. Ocena przygotowania administracji, Warszawa

Leśniewski M., 2003, Małe i średnie firmy - sól Unii, „Home \& Market”, nr 7-8, s. 48-49

Kaliszuk A., 2003, Mali i średni przedsiębiorcy, [w:] Programy Unii Europejskiej dla Polski. Przewodnik, Przedstawicielstwo Komisji Europejskiej w Polsce, Warszawa

PHARE 2000 dla Polski Wschodniej i Ślaska. Ocena przygotowania administracji, Warszawa

Rachtan P., 2003, Polska Przedsiębiorczość, „Nowe Życie Gospodarcze”, nr 12, s. 4-7

Tworos P., 2000, Pomoc Unii Europejskiej dla krajów Europy Środkowej i Wschodniej w latach dziewięćdziesiatych, [w:] Droga do Funduszy Strukturalnych Unii Europejskiej, red. C. Gołębiowski et al, Polska Agencja Rozwoju Regionalnego, Warszawa

Ważniewski P., 2003, Sektor matych i średnich przedsiębiorstw w Polsce i w Unii Europejskiej, „Gospodarka Narodowa", nr 5-6, s. 78-90

6 Program ramowy badań i rozwoju technicznego (2002-2006) - przewodnik dla wnioskodawców, 2002, Komisja Europejska, PAN, Warszawa

www.parp.gov.pl

www.delpol.pl

www.cie.gov.pl

www.6pr.pl 